\title{
Spatial Variations in Cooling Rate in the Mantle Section of the Samail Ophiolite in Oman: Implications for Formation of Lithosphere at Mid- Ocean Ridges
}

\author{
Nick Dygert $^{1} *$, Peter B. Kelemen ${ }^{2}$, Yan Liang ${ }^{3}$
}


Abstract

To understand how the mantle cools beneath mid-ocean ridge spreading centers, we

42 applied a REE-in-two-pyroxene thermometer and major element thermometers to peridotites

43 from the Wadi Tayin massif in the southern part of the Samail ophiolite in the Sultanate of

44 Oman, which represent more than $10 \mathrm{~km}$ of structural depth beneath the paleo-Moho. Closure

45 temperatures for REEs in pyroxenes deduced from the REE-in-two-pyroxene thermometer $\left(T_{R E E}\right)$

46 decrease smoothly and systematically with depth in the section, from $>1300^{\circ} \mathrm{C}$ near the crust to

$47<1100^{\circ} \mathrm{C}$ near the metamorphic sole, consistent with previously observed, similar variations in

48 mineral thermometers with lower cooling temperatures. Estimated cooling rates decrease from

$49 \sim 0.3{ }^{\circ} \mathrm{C} / \mathrm{y}$ just below the crust-mantle transition zone (MTZ) to $\sim 10^{-3}{ }^{\circ} \mathrm{C} / \mathrm{y}$ at a depth of six $\mathrm{km}$

50 below the MTZ. Cooling rates derived from Ca-in-olivine thermometry also decrease moving

51 deeper into the section. These variations in cooling rate are most consistent with conductive

52 cooling of the mantle beneath a cold overlying crust. In turn, this suggests that hydrothermal

53 circulation extended to the MTZ near the axis of the fast-spreading ridge where the igneous crust

54 of the Samail ophiolite formed. These observations are consistent with the Sheeted Sills model

55 for accretion of lower oceanic crust, and with previous work demonstrating very rapid cooling

56 rates in the crust of the Wadi Tayin massif. Our observations, combined with previous results,

57 suggest that efficient hydrothermal circulation beneath fast spreading centers cools the

58 uppermost mantle from magmatic temperatures to $<1000^{\circ} \mathrm{C}$ as quickly as tectonic exhumation at

59 amagmatic spreading centers. In contrast, thermometers sensitive to cooling over lower

60 temperature intervals indicate that the Wadi Tayin peridotites cooled more slowly than

61 tectonically exhumed peridotites sampled near the seafloor along mid-ocean ridges.

62 Hydrothermal cooling of the crust may have waned, so that the crust-mantle package cooled 
63 more slowly, whereas rapid cooling of abyssal peridotites during tectonic exhumation continued

64 to seafloor temperatures.

65

66 Keywords: Mantle, REE, thermometry, Oman ophiolite, diffusion, closure temperature,

67 geospeedometry

68 


\section{Introduction}

Geothermometers are widely used to investigate the thermal history of mafic and

71 ultramafic rocks. They utilize the temperature dependent solubility or partitioning of a

72 component among phases in a mineral assemblage, allowing temperatures to be calculated from

73 measured mineral compositions. Geothermometers are calibrated experimentally or with well-

74 equilibrated natural samples, and depending on the thermometer, take advantage of temperature

75 dependent major element (e.g., Boyd, 1973; Brey and Köhler, 1990; Nickel and Green, 1985;

76 Putirka, 2008; Wells, 1977; Witt-Eickschen and Seck, 1991; Wood and Banno, 1973) and/or

77 trace element exchange reactions (Eggins et al., 1998; Lee et al., 2007; Liang et al., 2013; Seitz

78 et al., 1999; Sun and Liang, 2015; Witt-Eickschen and O’Neill, 2005).

79 The physical meaning of a temperature derived from the application of a geothermometer

80 to a natural sample depends on its thermal history. In cases where the sample is maintained at

81 constant pressure and temperate conditions and then rapidly exhumed or erupted, any well

82 calibrated geothermometer should give a temperature reflecting the condition of equilibration in

83 agreement with other thermometers (e.g., Liang et al., 2013; Smith, 2013; Witt-Eickschen and

84 Seck, 1991). No kinetic information is preserved in such samples. In contrast, if the sample cools

85 sufficiently slowly to allow appreciable diffusive reequilibration to occur during cooling,

86 geothermometers will give a range of temperatures. All will record higher temperatures for faster

87 cooling rates, providing the basis for "geospeedometry" (e.g., Dodson, 1973; Lasaga et al., 1983;

88 Ozawa, 1984), a powerful tool that has been widely used to study the thermal history of crust and

89 mantle formed at oceanic spreading ridges (e.g., Coogan et al., 2002, 2005a, 2007a,b; Dygert and

90 Liang, 2015; Faak et al., 2015; Faak and Gillis, 2016; VanTongeren et al., 2008). In addition, the

91 temperature recorded by a given thermometer will depend on the effective diffusion rates of the 
92 components used to calibrate the thermometer. Thermometers based on slowly diffusing

93 elements record higher temperatures than those based on faster diffusing elements (e.g., for

94 peridotites, Dygert and Liang, 2015; Hanghøj et al., 2010; Liang et al., 2013; Müntener et al., 95 2010; Yao and Liang, 2015).

96 In this work we will discuss temperatures from three types of thermometers. (1) The

97 REE-in-two-pyroxene thermometer of Liang et al. (2013), which utilizes the composition-

98 dependent temperature sensitivity of exchange of trivalent REEs+Y between orthopyroxene

99 (opx) and clinopyroxene (cpx). (2) Two-pyroxene solvus thermometers (e.g., Brey and Köhler,

100 1990; Lindsley, 1983; Lindsley and Anderson, 1983; Wells, 1977), which parameterize

101 temperature sensitive "transfer of the enstatite component between coexisting ortho- and

102 clinopyroxene" around the solvus (Brey and Köhler, 1990). In reality, this exchange reaction is

103 more complicated as unmixing of solid solutions during cooling involves coupled diffusion of

104 several major elements (e.g., $\mathrm{Ca}, \mathrm{Mg}$ and $\mathrm{Si}$ ), and net growth of one phase at the expense of

105 another. (3) Cation exchange thermometers, which parameterize the temperature sensitivity of

106 exchange of major elements between two phases (e.g., Fabriès, 1979; Köhler and Brey, 1990).

107 For samples that cooled slowly, thermometers based on exchange of trivalent elements (e.g.,

108 REEs, Al) give temperatures tens to hundreds of degrees higher than two-pyroxene solvus

109 thermometers, which in turn give higher temperatures than divalent cation exchange

110 thermometers (e.g., D’Errico et al., 2016; Dygert and Liang, 2015; Liang et al., 2013; Marchesi

111 et al., 2016; Müntener et al., 2010; Sun and Liang, 2015; Wang et al., 2015; Witt-Eickschen \&

112 Seck, 1991). These differences in temperature can be attributed to slower diffusion of trivalent

113 elements compared to divalent elements (e.g., Chakraborty, 2010; Cherniak and Dimanov, 2010 
114 and references therein), and the slower diffusion of multivalent mineral components compared to

115 interdiffusion of isovalent cations.

116 As a general rule, the larger the difference between the temperatures given by

117 thermometers based on trivalent elements and solvus or cation exchange thermometers, the

118 slower the average cooling rate for the sample. Thermometers based on trivalent cation exchange

119 may reflect cooling rates in high temperature intervals along the cooling path; solvus

120 thermometers may reflect cooling rates in intermediate temperature intervals along the cooling

121 path. Divalent cation exchange thermometers are sensitive to lower temperature cooling

122 intervals, and among themselves, are sensitive to cooling at different temperatures, with

123 thermometers based on the fastest diffusing cations reflecting cooling over the lowest

124 temperature intervals.

125 In a recent study, Dygert and Liang (2015) applied the REE-in-two-pyroxene

126 thermometer of Liang et al. (2013) and several solvus thermometers to abyssal peridotites and

127 peridotites sampled from the mantle section of ophiolites. Some ophiolites cooled more slowly

128 than abyssal peridotites. This was expected, as abyssal peridotites are dredged from mantle

129 exposures that were tectonically exhumed along transform faults and detachment faults in less

130 than a million years, while ophiolites have crustal sections that generally act as insulating

131 barriers for underlying mantle peridotites for many millions of years. In contrast, peridotites

132 from the northern Samail ophiolite appear to have cooled as quickly as the abyssal peridotites

133 based on REE thermometry. This is surprising as the Samail ophiolite has a thick (5-7km) crustal

134 section and probably formed at a fast-spreading center (e.g., Nicolas, 1989; Rioux et al., 2012,

135 2013, 2016; Tilton et al., 1981), suggesting that cooling of the mantle beneath mid-ocean ridges 
136 is independent of spreading rate and the presence or absence of crust, at least in the temperature 137 interval from $\sim 1300$ to $1000^{\circ} \mathrm{C}$.

138 To investigate the thermal history of mantle peridotites beneath thick crustal sections, as 139 compared to mantle peridotites that are tectonically exhumed along faults near mid-ocean ridges, 140 we applied the REE-in-two-pyroxene thermometer (Liang et al., 2013) and conventional major 141 element-based pyroxene solvus, olivine-cpx and olivine-spinel cation exchange thermometers 142 (Brey and Köhler, 1990; Fabriès, 1979; Köhler and Brey, 1990; Putirka, 2008; Wells, 1977; 143 Witt-Eickschen and Seck, 1991) to a suite of samples from the Wadi Tayin massif in the 144 southern Samail ophiolite (Figure 1), previously studied by Hanghøj et al. (2010). Corrected for 145 structural depth beneath the paleo-Moho, assuming that there is a constant dip parallel to the 146 crust-mantle transition, and that there are no faults that repeat or omit section, these samples 147 represent more than $10 \mathrm{~km}$ of paleo-depth below the Moho, with continuous outcrop. Samples 148 from this section can thus be used to investigate the dependence of cooling rate on depth beneath 149 the crust.

150 Our focus on the Wadi Tayin massif was motivated by the observation of large gradients 151 in major element thermometer temperatures across the mantle section, with higher temperatures 152 in mantle samples near the base of the crust and lower temperatures deeper in the section (Fig. 2, 153 also see Fig. 7 in Hanghøj et al., 2010). In addition, interpretation of closure temperatures for 154 olivine-cpx Ca-Mg exchange indicates that the entire crustal section in the Wadi Tayin massif 155 cooled very rapidly, with no systematic gradient in cooling rate with depth in the crust 156 (VanTongeren et al., 2008).

157 The southern massifs of the Samail ophiolite show some geochemical characteristics 158 indicative of a "subduction component" (e.g., Pearce et al., 1981 and recent reviews in MacLeod 
159 et al., 2013 and Rioux et al., 2016), but also record a fast rate of submarine, sea-floor spreading 160 (Rioux et al., 2012, 2013; Tilton et al., 1981). The massifs have a well-developed, gabbroic

161 lower crust underlying sheeted dikes and pillow basalts, with mid-ocean ridge basalt (MORB)-

162 like parental magmas and trace element chemistry, and they have mantle composition similar to 163 abyssal peridotites (e.g., Braun, 2004; Garrido et al., 2001; Godard et al., 2000; Hanghøj et al., 164 2010; Kelemen et al., 1995; 1997; Nicolas, 1989; Pallister and Knight, 1981). Thus, the southern 165 massifs of the Samail ophiolite in Oman represent the ophiolites with the greatest affinities to 166 crust formed at fast-spreading mid-ocean ridges. As a result, our study provides new insight into

167 the processes that cool the mantle beneath present-day, fast-spreading mid-ocean ridges such as 168 the East Pacific Rise.

\section{Samples and Mineral Compositions}

Here we report major element compositions from analyses of opx, cpx and olivine and 172 trace element compositions of opx and cpx in eight peridotites from the OM94 traverse originally 173 studied by Hanghøj et al. (2010) (Fig. 3, Supplementary Tables S1 and S2, Supplementary Figs. 174 S2-S5). Analytical methods are described in the Electronic Supplement. The samples are 175 depleted, plagioclase-free harzburgites. Pyroxene minor element concentrations plot at the 176 depleted ends of the ophiolitic and abyssal peridotite fields (Figs. 3a, 3b, Supplementary Figs. 177 S2, S3). Consistent with the depleted pyroxene compositions, bulk rock REE and other 178 incompatible trace element characteristics in Wadi Tayin peridotites overlap the low end of the 179 compositional range for abyssal peridotites (Fig. 3a in Hanghøj et al., 2010). Similarly, spinel 180 Cr\#s in the Wadi Tayin and adjacent Samail massif mantle sections range from 35 to 73 (Cr\# =

181 100x molar $\mathrm{Cr} /(\mathrm{Cr}+\mathrm{Al})$; Braun, 2004; Hanghoj et al., 2010; Koga et al., 2001; Korenaga and 
182 Kelemen, 1997), overlapping the high end of the range in depleted abyssal peridotites (maximum 183 Cr\# 60) and extending to slightly higher values (e.g., Dick and Bullen, 1984; updated 184 compilation in Fig. 5 of Hanghoj et al., 2010). With the exception of one sample that has slightly 185 elevated REE concentrations and may have experienced late-stage melt infiltration (OM94-114, 186 Hanghøj et al., 2010), REEs in cpx overlap the low ends of the fields defined by abyssal 187 peridotites and ophiolites (Fig. 3 in Kelemen et al., 1995). REE concentrations are generally 188 higher in samples deep in the section, and lower close to the Moho, consistent with increasing 189 extents of depletion with decreasing depth, due to decompression melting and melt extraction.

190 This agrees with the previous observation that spinel Cr\# in harzburgites increases upward from 191 the base of the section toward the Moho (Hanghøj et al., 2010). Other major elements exhibit

192 little systematic variation as a function of distance from the Moho (Supplementary Fig. S5). 193 Overall, these observations suggest that the Wadi Tayin peridotites are residues of 194 decompression melting beneath a spreading center similar to a fast-spreading mid-ocean ridge.

\section{Temperatures and Cooling Rates}

Temperatures obtained using the REE-in-two-pyroxene thermometer of Liang et al.

198 (2013) and solvus and cation exchange thermometers developed by Brey and Köhler (1990), 199 Köhler and Brey (1990), and Fabriès, 1979 are plotted in Fig. 2 as a function of distance from 200 the paleo-Moho. Brey and Köhler's Ca-in-opx thermometer $\left(T_{C a-i n-O p x}\right)$ is based on the Ca content 201 of opx along the solvus between two pyroxenes, and their two-pyroxene thermometer $\left(T_{B K N}\right)$ 202 parameterizes unmixing along the solidus to form cpx with different proportions of the diopside 203 component. Köhler and Brey's Ca-in-olivine thermometer $\left(T_{\mathrm{Ca}-\mathrm{in}-\mathrm{Ol}}\right)$ is based on $\mathrm{Ca}-\mathrm{Mg}$ exchange 204 between olivine and clinopyroxene. The olivine-spinel thermometer ( $\left.T_{O l-S p}\right)$ of Fabriès 
parameterizes Fe-Mg exchange between the two minerals. For each sample, the thermometers

206 give different temperatures, but the variation in $T_{R E E}, T_{B K N}, T_{C a-i n-O p x}$, and $T_{C a-i n-O l}$ is fairly well-

207 correlated. For those thermometers, samples near the paleo-Moho have higher temperatures than

208 samples deeper in the section, as previously shown for $T_{B K N}$, and $T_{C a-i n-O p x}$ by Hanghøj et al.

209 (2010, see their Fig. 7). As shown in Fig. 2, $T_{R E E}$ exhibit a smooth and systematic decrease from

$210>1300^{\circ} \mathrm{C}$ near the crust to $<1100^{\circ} \mathrm{C}$ at the bottom of the section, while $T_{C a-i n-O p x}$ and $T_{B K N}$ show

211 slightly different patterns, with highest temperatures near the crust $\left(T_{B K N}=1060^{\circ} \mathrm{C}, T_{C a-i n \text { - }}\right.$

$\left.212 o_{p x}=1127^{\circ} \mathrm{C}\right)$, lowest temperatures in the middle of the section $\left(T_{B K N}=718^{\circ} \mathrm{C}, T_{C a-i n-O p x}=892^{\circ} \mathrm{C}\right)$,

213 and intermediate temperatures near the ophiolite's metamorphic sole $\left(T_{B K N}=834^{\circ} \mathrm{C}, T_{C a-i n \text { - }}\right.$

$\left.214 o_{p x}=961^{\circ} \mathrm{C}\right) \cdot T_{C a-i n-O l}$ decrease from a high of $855^{\circ} \mathrm{C}$ near the crust to a low of $633^{\circ} \mathrm{C}$ in the

215 middle of the section. Aside from a sample with a slightly higher temperature near the crust, $T_{O l-}$

$216 S p$ shows no significant variation with depth, as is true for temperatures determined using the Al-

217 in-opx thermometer of Witt-Eickschen and Seck (1991) (Table 1). However, the OM94 pyroxene

218 compositions fall outside the calibration range of the empirical Al-in-opx thermometer.

219 Temperatures determined using the REE-in-two-pyroxene thermometer are plotted versus

$220 T_{B K N}$ and $T_{C a-i n-O p x}$ in Figs. $4 \mathrm{a}$ and $4 \mathrm{~b}$. In addition to samples from Oman and other ophiolites,

221 abyssal peridotites and subcontinental peridotites from thermally stable environments are shown

222 (plots for other thermometers are presented in Supplementary Fig. S1). The two OM94 samples

223 nearest to the paleo-Moho have $T_{B K N}$ and $T_{C a-i n-O p x}$ similar to those in abyssal peridotites and

224 slightly higher $T_{R E E}$ than the abyssal peridotites. They have major element temperatures

225 overlapping those for other samples from Oman but higher $T_{R E E}$. Samples from the OM94

226 traverse deeper in the Wadi Tayin section record lower temperatures than abyssal peridotites,

227 overlapping those of other ophiolites. The similar distribution of data in Figs. 4a and 4b 
228 demonstrates that the temperature systematics we observe are not an artifact of a particular

229 thermometer (e.g., also see Supplementary Fig. S1c). Fig. 4c compares $T_{O l-S p}$ and $T_{C a-i n-O l}$ for

230 peridotites from Oman, other ophiolites, and abyssal peridotites. Oman samples have lower $T_{O l-S p}$

231 than many abyssal peridotites and lower $T_{\mathrm{Ca}-\mathrm{in}-\mathrm{Ol}}$ than most abyssal peridotites, which is true of

232 all ophiolites.

233 To interpret the physical meaning of the temperatures recorded by major and REE-based

234 thermometers, we must consider the concept of closure temperature, and evaluate whether the

235 temperatures we observe qualify as closure temperatures. Closure temperature is defined as the

236 lower temperature limit at which diffusive exchange of an element (or component) between a

237 mineral and its surroundings effectively ceases during cooling (Dodson, 1973). For a mineral

238 surrounded by an effectively infinite reservoir, Dodson's equation for closure temperature, $T_{c}$, is

239 given by

240

$$
\frac{E}{R T_{c}}=\ln \left(\frac{A R T_{c}^{2} D_{0}}{E a^{2} \dot{s}}\right),
$$

241 where $E$ and $D_{0}$ are the activation energy and the pre-exponential factor for diffusion of the 242 element of interest, respectively; $A$ is a geometric constant (here we assume a sphere); $a$ is an 243 effective grain size; $\dot{s}$ is the cooling rate at $T_{c}$; and $R$ is the gas constant. In this formulation, $T_{c}$ is 244 the mean or average closure temperature across the mineral grain. We will use the mean closure 245 temperature or closure temperature, for short, in our discussion below.

246 In a majority of published studies, temperatures derived from major or trace element-

247 based thermometers for a sample are calculated using average concentrations based on chemical 248 analysis of several mineral grains in a thin section. It is reasonable to interpret major element 249 exchange thermometer temperatures as the mean closure temperatures or proxies for closure 250 temperatures if (1) analytical quality is good and representative, and (2) the sample of interest 
251 had a simple thermal history, i.e., not disturbed by melt infiltration, metasomatism, or another 252 geologic processes. $T_{R E E}$ are more difficult to interpret, as the REE-in-two-pyroxene 253 thermometer depends on major and trace element exchange between two pyroxenes, and gives a 254 single temperature for all REEs+Y. Numerical simulations of REE diffusive exchange between 255 pyroxenes in cooling opx-cpx aggregates (Yao and Liang, 2015), and comparisons among 256 natural samples from a variety of tectonic environments (including subcontinental mantle, mid257 ocean ridge spreading centers, subduction zones, incipient rifts, and ophiolites, Dygert and 258 Liang, 2015; Liang et al., 2013; Sun and Liang, 2015; Wang et al., 2015) indicate $T_{R E E}$ reflect 259 average closure temperatures for diffusive exchange of REEs+Y between opx and cpx. This is 260 further supported by the small $T_{R E E}$ uncertainties for the OM94 samples, which depend on the 261 linearity of the $T_{R E E}$ inversions (i.e., the consistency among $T_{R E E}$ given by individual REEs, 262 Supplementary Fig. S11). Collectively, the new major and trace element data reported here (Fig. 263 3, Supplementary Tables S1 and S2), systematic variations of $T_{R E E}, T_{C a-i n-O p x}, T_{B K N}$, and $T_{C a-i n-O l}$ 264 with depth (Figure 2), and linearity of the temperature inversions suggest the $T_{R E E}$ temperatures 265 recorded by the Wadi Tayin peridotites can also be considered closure temperatures (see 266 discussion below for one or two exceptions and further analysis).

267 Closure temperatures from two thermometers can be used to estimate an average cooling 268 rate for a sample by comparison of the temperatures. This method requires that (1) the relative 269 reequilibration rates for the thermometers can be reasonably assumed, (2) the sample of interest 270 was in chemical equilibrium at an initial high temperature and cooled to its closure temperature 271 at a constant rate in a closed system, (3) the rate of grain growth is insignificant compared to the 272 rate of cooling, and (4) grain size is known. Using approximate solutions to diffusion equations 273 for bimineralic systems, Liang (2014) showed that for two minerals, diffusive reequilibration 
274 rates follow the "minor's rule", which states the mineral with the lesser amount of a trace

275 element in the system controls the reequilibration timescale. This idea was further explored in

276 numerical simulations of REE redistribution in two pyroxene systems by Yao and Liang (2015),

277 and by Liang (2015), who developed a generalized closure temperature equation for bimineralic

278 systems. These studies found that, except in peridotites with very little cpx $\left(\phi_{c p x} / \phi_{o p x}<0.05\right.$,

279 where $\phi$ is the volume fraction of the mineral), REE diffusion in opx determines reequilibration

280 timescales for the REE-in-two-pyroxene thermometer. This is an intuitive result; because

281 opx/cpx partition coefficients are generally $<0.05$ and decrease further with decreasing

282 temperature (e.g., Sun and Liang, 2014), unless cpx abundance is very low, most REEs in

283 peridotites reside in cpx. Thus, in cases where $\phi_{c p x} / \phi_{o p x}>0.05$, cpx can be treated as a semi-

284 infinite reservoir for REEs and most temperature-sensitive reequilibration will take place in

285 REE-poor opx. Calculated using bulk major element analyses from Hanghøj et al. (2010),

286 normative cpx/opx for most OM94 samples are >0.08 (Supplementary Table S3). (These

287 normative estimates may or may not be representative of the thin sections we analyzed, as the

288 cpx/opx content of the subsamples used to make the thin sections may differ from the

289 subsamples analyzed for bulk composition). Because diffusion of REEs in opx is not sensitive to

290 REE ionic radius (Cherniak and Liang, 2007), individual REEs should all record the same $T_{R E E}$

291 for a given sample with $\phi_{c p x} / \phi_{o p x}>0.05$. This is suggested by the linearity of the eight OM94

292 samples in the $T_{R E E}$ inversion diagrams (Supplementary Fig. S11).

293 An effective Arrhenius relation for inter or chemical diffusion of major elements

294 involved in the two pyroxene thermometer of Brey and Köhler (1990) is difficult to interpret, as

295 this thermometer relies on exchange of the enstatite component between coexisting cpx and opx,

296 and growth of cpx along the pyroxene solvus during cooling. Cpx growth during cooling is only 
297 volumetrically significant relative to cpx present at magmatic temperatures for Ca-poor samples.

298 According to mineral norms for OM94 peridotites (Supplementary Table S3), cpx grown at

299 subsolidus temperatures is minor relative to cpx present at magmatic temperatures in 6 of the 8

300 samples investigated here. For the samples that experienced insignificant cpx growth during

301 cooling, $T_{B K N}$ closure temperatures may be reasonably approximated by Arrhenius relations for

$302 \mathrm{Ca}-\mathrm{Mg}-\mathrm{Fe}$ exchange between diopside and enstatite. As diffusion data needed to model this

303 exchange are not currently available, Dygert and Liang (2015) compared $T_{B K N}$ for ophiolitic

304 peridotites to closure temperatures calculated using Fe-Mg diffusion coefficients from 7 sources

305 and Dodson's closure temperature equation, ultimately selecting an Arrhenius relation for $\mathrm{Fe}-\mathrm{Mg}$

306 interdiffusion in cpx (Dimanov and Wiedenbeck, 2006). This choice best matches temperatures

307 in $T_{R E E}$ and $T_{B K N}$ space recorded by slow cooling peridotites. According to Eq. 1, they should

308 converge to a line left of and sub-parallel to the 1:1 line in Fig. 5 (also see Figure 8 in Dygert and

309 Liang, 2015). Choosing an Arrhenius relation allows us to calculate cooling rates which should

310 be accurate relative to each other for OM94 samples that are not very cpx poor.

311 Figure 5 presents closure curves constructed using a modified form of Dodson's equation

312 (Ganguly and Tirone, 1999), which models the dependence of closure temperature $\left(T_{c}\right)$ on grain

313 size, initial temperature, and cooling rate, assuming the closure of $T_{R E E}$ are rate-limited by

314 diffusion of REEs in opx (Cherniak and Liang, 2007) and the closure of $T_{B K N}$ are approximated

315 by diffusion of Fe-Mg in cpx (Dimanov and Wiedenbeck, 2006). We emphasize that (1) this

316 method assumes one-stage cooling at constant rates and grain size, (2) gives an average cooling

317 rate over the temperature interval recorded by the thermometers. Closure curves are presented for

318 a range of initial temperatures (as indicated right of the 1:1 line). Numbers above the hottest

319 cooling curve are cooling rates in ${ }^{\circ} \mathrm{C} / \mathrm{y}$. As demonstrated by the closure curves, the position of a 
320 sample in temperature space generally indicates its relative cooling rate, with samples farther

321 from the 1:1 line experiencing slower cooling. These closure curves were calculated for an

322 effective and constant grain radius of $0.5 \mathrm{~mm}$ but can be scaled to other grain sizes as $T_{c}$ varies

323 with radius squared (Eq. 1). Because pyroxene grain size varies by orders of magnitude among

324 natural samples, scaling to measured grain sizes is critical when using this method to estimate

325 cooling rates.

326 Assuming one-stage cooling, the path of a sample in temperature space is as follows:

327 Starting on the 1:1 line, it moves left along a cooling curve corresponding to its initial 328 temperature. If it cools sufficiently slowly, the sample will then move diagonally downward 329 along the curve given by Eq. 1. Samples that fall to the left of the cooling curves may record 330 closure temperatures that are not meaningful due to geochemical disturbance (e.g., melt-rock

331 interaction), data quality issues, complex cooling histories that are difficult to interpret using 332 closure temperatures alone, or have been cpx-free at magmatic temperatures. It is important to 333 reiterate the need of accurate diffusion data in modeling the closure of relevant major and trace

334 elements in the two-pyroxene systems. Future study should also consider effects of major 335 element composition and pressure on cation diffusion and closure temperatures in pyroxenes.

336 Five of the eight OM94 samples plot along a single cooling curve corresponding to an 337 apparent initial temperature of $\sim 1330^{\circ} \mathrm{C}$. We interpret the three outliers as follows: The sample 338 that falls far to the left of the cooling curve (OM94-98) has small cpx (80-150 $\mu \mathrm{m}$ in diameter) 339 hosted by large opx grains (Supplementary Figure S7) and low bulk Ca, suggesting all of its cpx 340 exsolved from opx at subsolidus temperatures. In a scenario where cpx grows from opx at low 341 temperature, REEs are likely to be depleted in a metamorphic halo in the host opx immediately 342 surrounding the growing cpx grain. This would starve the growing cpx of REEs. Because 
343 opx/cpx REE partition coefficients decrease with decreasing temperature (Eggins et al., 1998;

344 Sun and Liang, 2014; Witt-Eickschen and O’Neill, 2005), analysis of cpx with artificially low

345 REE concentrations in cpx, together with "correct" REE concentrations in opx away from the

346 depletion halo, would lead to artificially high $T_{R E E}$. Such a sample would also have a low $T_{B K N}$.

347 Thus, we infer that OM94-98 does not provide closure temperatures relevant to the high-

348 temperature cooling history of the ophiolite. The other two samples that plot away from the

349 cooling curve defined by five samples, to the right of the cooling curve (OM94-61, OM94-67),

350 are at the base of the mantle section of the ophiolite, near the metamorphic sole. Thus, these two

351 samples may record a thermal disturbance related to obduction. (We caution that one of these

352 samples, OM94-61, has low bulk Ca and may have been cpx-free at magmatic temperatures).

353 Apparent cooling rates obtained from the closure curves (corrected for measured grain

354 sizes) are plotted as a function of distance from the paleo-Moho in Figure 6 (red and blue

355 squares), and presented in Table 1. The cooling rates mimic the closure temperatures; they are

356 high near the paleo-Moho $\left(\sim 0.3^{\circ} \mathrm{C} / \mathrm{y}\right)$, gradually decreasing to a minimum in the middle of the

357 section $\left(\sim 10^{-3}{ }^{\circ} \mathrm{C} / \mathrm{y}\right)$ before an apparent increase at the base $\left(\sim 5 \times 10^{-3}{ }^{\circ} \mathrm{C} / \mathrm{y}\right)$. Shown for

358 comparison are cooling rates obtained using Ca-in-olivine thermometry (Köhler and Brey, 1990)

359 and Dodson's (1973) equation (white and green circles) using a diffusion coefficient for Ca in

360 olivine from Coogan, 2005b (parallel to c-axis). Rates for samples from the crustal section

361 (unfilled circles, VanTongeren et al., 2008) agree with rates for the mantle section (green circles,

362 this study), and the fast cooling rates obtained using $T_{R E E}$ and $T_{B K N}$ for peridotites closest to the

363 Moho. This consistency is striking, especially as the cooling rates were obtained using different

364 minerals, thermometers, and methods. 
Previous studies applying olivine-spinel geospeedometers to ophiolitic peridotites have

366 obtained cooling rates somewhat consistent with our results. Investigating dunites from Wadi

367 Bani Kharus in the Nakhl massif of the Samail ophiolite in Oman, Coogan et al. (2007b) found

368 rates of $\sim 10^{-2}{ }^{\circ} \mathrm{C} / \mathrm{y}$ near the Moho, $\sim 10^{-3}{ }^{\circ} \mathrm{C} / \mathrm{y}$ in the interior of the mantle section, and $\sim 10^{-2}{ }^{\circ} \mathrm{C} / \mathrm{y}$

369 at the basal thrust. Ozawa (1984) found cooling rates of $\sim 10^{-4}-10^{-2}{ }^{\circ} \mathrm{C} / \mathrm{y}$ for peridotites from

370 several Japanese ophiolites (Horoman, Iwanaidake, and Miyamori). Rapid Fe-Mg diffusion

371 makes olivine-spinel thermometers sensitive to low temperature cooling processes and spinel

372 grain size, which may explain some of the inconsistency with our observations; choice of

373 diffusion data also significantly affects calculated cooling rates.

\section{4. Interpretations}

Our next task is to understand what physical processes could have brought about the 377 spatial variations in closure temperatures and cooling rates with depth in the mantle section. The 378 cooling history of the oceanic upper mantle is intimately related to the cooling history of the 379 overlying crust. A body of literature has explored the thermal history of the oceanic crust in an 380 effort to evaluate mechanisms of crustal accretion (e.g., Coogan et al., 2002; Coogan et al., 381 2007b; Faak et al., 2015; Faak and Gillis, 2016; Garrido et al., 2001; VanTongeren et al., 2008).

382 There are two end-member crustal accretion models; in the Gabbro Glacier model, lower oceanic 383 crust accretes from crystallization in a single magma chamber beneath the axis of a spreading 384 center (Henstock et al., 1993; Phipps Morgan and Chen, 1993; Quick and Denlinger, 1993; 385 Sinton and Detrick, 1992; Sleep, 1975). Newly formed crust advects downward from the magma 386 chamber floor and away from the ridge axis as seafloor spreading progresses. In contrast, in the 387 Sheeted Sills model, oceanic crust accretes from crystallization of small sills at many depths 
within the lower crust, and the sills were emplaced at depths they are observed today (Kelemen et al., 1997; Korenaga and Kelemen, 1998; VanTongeren et al., 2008; 2015). Hybrid models that combine features of these two end-members have also been proposed (e.g., Boudier et al., 1996). In fact, even the schematic sheeted sill illustrations of Kelemen et al. (1997) and Korenaga and 392 Kelemen (1998) include a small gabbro glacier forming the uppermost part of the plutonic 393 oceanic crust.

The end-member crustal accretion models have different requirements for crustal cooling.

395 The Sheeted Sills model requires deep and efficient hydrothermal circulation beneath the ridge 396 axis to accommodate latent heat produced by crystallization of the sills (e.g., Maclennan et al., 397 2004). The Gabbro Glacier model requires that immediately beneath the ridge axis, hydrothermal 398 circulation is limited to the extrusive section of the crust, while the lower crust and underlying 399 mantle cool mainly by conduction. (This might not preclude deep hydrothermal circulation 400 within a few $\mathrm{km}$ of the mid-ocean ridge axis around a very tall and narrow Gabbro Glacier, 401 Buck, 2008.) Making the simplifying assumptions that the lower crust and the uppermost mantle 402 have the same initial temperature, and that heat conduction in the direction of seafloor spreading 403 can be neglected, we can test whether the observed cooling rates are consistent with conductive 404 cooling of the crust and mantle (and by extension, the Gabbro Glacier model) using a half-space 405 solution to the one-dimensional heat conduction equation,

$$
T=\left(T_{1}-T_{0}\right) \times \operatorname{erf}\left(\frac{z}{2 \sqrt{\kappa t}}\right)+T_{0}
$$

407 where $T_{1}$ is the initial temperature of the rock and $T_{0}$ is the temperature at the rock-seawater 408 interface; $z$ is the depth beneath the seafloor; $t$ is time; and $\kappa$ is thermal diffusivity (Eq. 4-125, 409 Turcotte and Schubert, 2002). Taking the derivative of Eq. 2 with respect to time gives the 410 instantaneous cooling rate, which varies nonlinearly in time at a given $z$. More useful is an 
411 average cooling rate calculated over the observed $T_{R E E}, T_{B K N}$, and $T_{C a-i n-O l}$ closure temperature 412 intervals of our samples.

413 The results of several models for conductive cooling of the lower crust and mantle are

414 presented in Figure 6a. Average cooling rates calculated over high temperature cooling intervals

415 (e.g., the magenta line, $1300-1000^{\circ} \mathrm{C}$ ) are faster than cooling rates calculated over lower 416 temperature intervals (e.g., the black line, $850-700^{\circ} \mathrm{C}$ ). These models underestimate cooling rates 417 recorded by crust and mantle rocks throughout the section, more importantly, they fail to match 418 the spatial variation of cooling rate with depth. We conclude that purely conductive cooling of 419 the lower crust and mantle is inconsistent with the closure temperatures and cooling rates 420 preserved at Wadi Tayin, suggesting the lower crust in that section was not emplaced in a gabbro 421 glacier.

422 A crustal cooling model from Cherkaoui et al. (2003) is shown in Figure 6b (purple 423 vertical line). Cherkaoui et al. (2003) incorporated both heat conduction and hydrothermal 424 circulation in their models, which provide a better match than purely conductive cooling models 425 to the crustal closure temperatures and corresponding cooling rates of VanTongeren et al. (2008) 426 in the Wadi Tayin massif. Intrigued by these results, we calculated cooling rate profiles for the 427 mantle assuming conductive cooling of the mantle section below the Moho, overlain by a cold 428 lower crust with constant temperature. (We used $200^{\circ} \mathrm{C}$, based on Cherkaoui et al., 2003; crustal 429 temperatures between 0 and $350^{\circ} \mathrm{C}$ would provide similar results). The correspondence between 430 the models and the curvature and magnitude of the cooling rate profiles suggests that the Wadi 431 Tayin mantle section cooled by conduction below a cold overlying crust, in agreement with the 432 Sheeted Sills model and the data of VanTongeren et al. (2008). These findings are consistent 433 with a recent investigation of lattice-preferred orientations in Wadi Tayin crustal gabbros 
434 (VanTongeren et al., 2015), which found no evidence for the plagioclase a-axis alignment that 435 would be produced by advection of crust from an axial magma chamber (required by the Gabbro 436 Glacier model). Instead, in the lower crust, girdles defined by plagioclase a-axes are 437 perpendicular to the paleo-Moho, consistent with the Sheeted Sills model.

438 Samples nearest to the paleo-Moho (which have $T_{R E E}>1300^{\circ} \mathrm{C}$ ) experienced very fast 439 cooling that effectively froze REE abundances in coexisting pyroxenes at magmatic 440 temperatures. Seawater infiltration caused by faulting would rapidly cool the mantle, but may 441 also produce a cooling rate profile with near-constant, fast cooling rates, unlike the gradual, 442 systematically decreasing cooling rates we observe (Figure 6). Our observations are most 443 consistent with efficient hydrothermal circulation that extended to (but not far beneath) the 444 crustal section. Serpentinization of the mantle at the paleo-Moho (and the associated volume 445 increase) may have formed a barrier to deeper circulation of seawater, preventing hydrothermal 446 cooling of the mantle, as previously proposed by Hanghøj et al. (2010). Thus, serpentinization of 447 ophiolitic peridotites may largely take place off axis, perhaps during or after obduction. Although the presently available data are admittedly limited, we interpret the pyroxene 449 solvus temperatures, with the associated, apparent increase in cooling rates at the base of the 450 section, as reflecting a late thermal disturbance related to obduction. The samples may have been 451 heated from below by frictional sliding along the ophiolitic sole after earlier closure of the major 452 and trace element thermometers. Because of the slow diffusion of REEs compared to major 453 elements, this could increase $T_{B K N}$ at $\sim$ constant $T_{R E E}$, moving the samples from the Dodson 454 (1973) closure temperature cooling curve rightward toward the 1:1 line (Figure 5). Alternatively, 455 the samples may have been quenched from below during obduction, requiring initiation of basal 456 thrusting while the mantle lithosphere was still young and hot (e.g., Hacker et al., 1996). 
Finally we turn to the $T_{O l-S p}$ and $T_{C a-i n-O l}$ systematics (Fig. 4c). The Ol-Sp and Ca-in-Ol

458 thermometers are based on exchange of relatively fast-diffusing mineral components and are thus

459 typically sensitive to cooling at temperatures $<1000^{\circ} \mathrm{C}$ (at mantle-relevant cooling rates). In

460 general, $T_{O l-S p}$ and $T_{C a-i n-O l}$ are lower for ophiolites than abyssal peridotites as noted previously by

461 Hanghøj et al., (2010), suggesting that ophiolites cool more slowly than abyssal peridotites at

462 temperatures $<1000^{\circ} \mathrm{C}$. This presents an interesting contrast to cooling of ophiolitic peridotites

463 and abyssal peridotites at high temperatures, which appears to occur at similar rates. Perhaps

464 hydrothermal cooling at the base of ophiolite crusts slows or stops during obduction, whereas

465 rapid cooling of peridotites in abyssal environments continues as they migrate to the seafloor by

466 tectonic exhumation.

\section{Summary and Conclusions}

Abyssal peridotites and samples from the mantle section of the Wadi Tayin massif of the

470 Samail ophiolite in Oman appear to have experienced similar high temperature cooling histories

471 (Dygert and Liang, 2015). Because abyssal peridotites are dredged from amagmatic

472 environments while the Oman ophiolite has a thick crust, the cooling rate of the mantle beneath

473 mid-ocean ridges in the temperature interval from $\sim 1300$ to $\sim 1000^{\circ} \mathrm{C}$ appears to be independent

474 of spreading rate or the presence or absence of crust. To understand what physical mechanisms

475 cool the mantle beneath mid-ocean ridges, we applied the REE-in-two-pyroxene thermometer of

476 Liang et al. (2013) and major element thermometers of Brey and Köhler (1990), Köhler and Brey

477 (1990), and Fabriès (1979) to peridotites from a transect through the mantle section of the Wadi

478 Tayin massif in the southern Samail ophiolite in Oman. Corrected for structural depth, the

479 section represents $10 \mathrm{~km}$ of mantle stratigraphy, making it suitable for investigating physical 
480 controls on cooling. Samples exhibit a statistically significant gradient in major element and 481 REE-in-two-pyroxene closure temperatures, with $T_{R E E}>1300^{\circ} \mathrm{C}$ near the paleo-Moho and $482<1100^{\circ} \mathrm{C}$ at the base of the section. Based on cooling curves constructed using Arrhenius 483 relations for $\mathrm{REE}$ and $\mathrm{Fe}-\mathrm{Mg}$ diffusion in pyroxene, we estimated cooling rates which vary 484 systematically throughout the section. The uppermost mantle was cooled from high temperature 485 at a rate $\left(\sim 0.3{ }^{\circ} \mathrm{C} / \mathrm{y}\right)$ consistent with previous estimates for the crust (VanTongeren et al., 2008). 486 Cooling was slowest $\sim 6 \mathrm{~km}$ beneath the paleo-Moho $\left(\sim 10^{-3}{ }^{\circ} \mathrm{C} / \mathrm{y}\right)$ and may have been slightly 487 faster near the ophiolitic sole $\left(\sim 5 \times 10^{-3}{ }^{\circ} \mathrm{C} / \mathrm{y}\right)$. Cooling rates calculated for the Ca-in-olivine 488 thermometer are slower, and also decrease moving deeper into the section. We used half-space cooling models to better understand our observations, which 490 demonstrate that conductive cooling alone underestimates cooling rates of rocks in the crust and 491 mantle. The spatial variation in cooling rates can be explained by conductive heat loss from the 492 mantle into a cold overlying crust, suggesting hydrothermal circulation extended to (but not far 493 beneath) the Moho at the ridge axis. These observations are most consistent with the Sheeted 494 Sills model for accretion of oceanic crust. A lack of hydrothermal circulation beneath the Moho 495 near the ridge axis suggests serpentinization of the mantle in ophiolites must largely take place 496 off axis, perhaps during or after obduction. Fast cooling at the base of the mantle section can be 497 attributed to frictional heating during obduction, or quenching associated with emplacement of 498 the ophiolite along the basal thrust while the mantle was still hot. This study suggests that 499 efficient hydrothermal cooling of the crust beneath mid-ocean ridges cools the uppermost mantle 500 through the temperature interval from $\sim 1300$ to $1000^{\circ} \mathrm{C}$ as quickly as tectonic exhumation in 501 amagmatic environments. Thermometers based on fast diffusing cations seem to record lower 502 closure temperatures and slower cooling rates for ophiolite samples compared to exhumed 
503 peridotites, perhaps because hydrothermal cooling slowed at the base of ophiolite crust during

504 obduction, whereas rapid cooling of peridotites in abyssal environments due to tectonic

505 exhumation continued to the seafloor. Overall, our new data demonstrate that the REE-in-two

506 pyroxene thermometer is a powerful tool for unraveling the high-temperature cooling history of

507 ultramafic rocks, placing new constraints on important tectonic and geophysical processes. We

508 hope this work motivates new efforts to model hydrothermal cooling beneath mid-ocean ridges,

509 more detailed investigations into the cooling histories of ophiolites and abyssal peridotites, and

510 additional studies of cation diffusion in pyroxene.

511

\section{Acknowledgements}

513 We thank Nathaniel Miller for assistance with LA-ICP-MS analyses. This paper

514 benefited from thoughtful reviews by Kathi Faak and an anonymous reviewer, and editorial

515 handling by Mike Bickle. This work was supported by a Jackson School of Geosciences

516 postdoctoral fellowship to N.D., NSF grant EAR-1632815 to Y.L., and NSF grants EAR-

517 1516300, EAR-1049905, Sloan Foundation Grant 2014-3-01, and International Continental

518 Drilling Program grant "Oman Drilling Project" to P.B.K.

\section{Figure Captions}

521 Figure 1. (a) A geologic map of the Wadi Tayin massif, Samail ophiolite, modified from

522 Hanghøj et al., 2010, and Nicolas et al., 2001. Inset shows the location of the massif in southern

523 Oman. Approximate locations of our samples are shown by the green circles. The green line

524 cutting across the sample area is the Makhibiyah shear zone, which is thought to have

525 accommodated little or no relative motion between the adjacent blocks (Nicolas and Boudier, 
526 2008). (b) The approximate depth of each sample beneath the crustal section, assuming that there

527 is a constant dip parallel to the crust-mantle transition, and that no faults repeat or omit section.

529 Figure 2. $T_{R E E}, T_{B K N}, T_{C a-i n-O p x}, T_{C a-i n-O l}$, and $T_{O l-S p}$ plotted as a function of distance from the 530 paleo-Moho for our OM94 samples. Note $T_{R E E}, T_{B K N}, T_{C a-i n-O p x}$, and $T_{C a-i n-O l}$ decrease moving

531 deeper into the section. Aside from a slight decrease at the top of the section, $T_{O l-S p}$ exhibits little 532 systematic variation with depth. $T_{R E E}, T_{B K N}$ and $T_{C a-i n-O p x}$ may reflect to high temperature cooling

533 histories while $T_{O l-S p}$ and $T_{C a-i n-O l}$ may reflect low temperature cooling histories. The sensitivity 534 of a thermometer to cooling over a particular temperature interval depends on its formulation 535 (see main text).

537 Figure 3. Pyroxene compositions in OM94 samples compared to abyssal and ophiolitic 538 peridotites. Abyssal peridotite data are from PetDB, and data for ophiolitic peridotites are from 539 the compilation of Dygert and Liang, 2015 (see caption to Fig. 4 for individual references). 540 Incompatible minor elements are shown in (a) cpx and (b) opx. Note the OM94 samples plot 541 with depleted abyssal and ophiolitic peridotites, suggesting high extents of partial melting. (c)

542 Chondrite normalized REEs in cpx from ophiolites and abyssal peridotites. REE patterns and 543 concentrations are similar to depleted abyssal peridotites, as also reflected in whole rock data for 544 REEs and other incompatible trace elements (Hanghøj et al., 2010, Figs. 3 and 4). 545 Concentrations of REEs in cpx generally increase moving deeper into the section, with the 546 exception of OM94-114 which may have experienced a melt infiltration event (Hanghøj et al., 547 2010). (d) Chondrite normalized REE concentrations in cpx (solid lines) and opx (dotted lines). 548 Error bars are $1 \sigma$ standard deviations of replicate analyses. 
550 Figure 4. Comparisons of temperatures derived from several geothermometers, additional 551 comparisons are shown in Supplementary Fig. S1. Gray circles (highlighted by peach fields in 552 (a) and (b)) are abyssal peridotites. Samples from Oman are large circles, other ophiolites are 553 shown as blue circles, red circles are subcontinental peridotites. (a) $T_{R E E}$ plotted against $T_{B K N}$. 554 Note that many samples from Oman have $T_{R E E}$ and $T_{B K N}$ similar to abyssal peridotites. This 555 suggests abyssal peridotites and Oman peridotites cooled at similar rates from initially high 556 temperatures. In contrast, samples from many other ophiolites have $T_{R E E}$ similar to abyssal 557 peridotites, but lower $T_{B K N}$. (b) $T_{R E E}$ plotted against $T_{C a-i n-O p x}$. As in (a), abyssal peridotites and 558 some samples from Oman have similar temperatures, while many ophiolites have lower $T_{C a-i n-O p x}$ 559 than the abyssal peridotites, demonstrating that the temperature systematics hold up for different 560 thermometers. (c) A comparison of $T_{O l-S p}$ and $T_{C a-i n-O l}$ temperatures. Because their 561 parameterizations are based on fast-diffusing mineral components, these thermometers are more 562 sensitive to the low temperature cooling history of a sample than the $T_{R E E}, T_{C a-i n-O p x}$, and $T_{B K N}$ 563 thermometers. The figure shows that samples from Oman and other ophiolites have lower $T_{O l-S p}$ 564 than many abyssal peridotites and lower $T_{\mathrm{Ca}-\mathrm{in}-\mathrm{Ol}}$ than most abyssal peridotites, suggesting that in 565 general, ophiolites cool more slowly than abyssal peridotites at low temperatures $\left(\lesssim 900^{\circ} \mathrm{C}\right)$. 566 Additional Oman data: Akizawa et al. (2016) are harzburgites from Wadi Fizh, Wadi Thuqbah, 567 Wadi Rajmi, and Wadi Sarami in central and northern Oman. They were mostly collected at 568 what are interpreted as paleo-spreading center segment ends. Three exceptions are from the 569 central portion of the Thuqbah massif, among them, $T_{R E E}$ is highest in a sample closest to the 570 paleo-Moho. Akizawa et al. (2012) are harzburgites from Wadi Fizh in the northern Samail 571 ophiolite, $\sim 5 \mathrm{~km} \mathrm{~W}$ of the Moho (distance in map view); Takazawa et al. (2003) is from 
572 deformed Wadi Fizh lherzolites near the basal thrust. Data sources for other ophiolites and

573 subcontinental peridotites are the following: Aldanmaz, 2012; Barth et al., 2003; Batanova et al.,

574 2011; Dygert and Liang, 2015; Dygert et al., 2016; Jean et al., 2010; Khedr et al., 2014;

575 Marchesi et al., 2011; Müntener et al., 2010; Riches and Rogers, 2011; Takazawa et al., 2003.

576 Data sources for abyssal peridotite $T_{R E E}$ are the following: Brunelli and Seyler, 2010; D'Errico et

577 al., 2016; Hellebrand et al., 2005; Seyler et al., 2011; Warren et al., 2009. Abyssal peridotite $T_{O l-}$

$578 S p$ and $T_{C a-i n-O l}$ are augmented with data for plagioclase-free samples from the compilation of

$579 \quad$ Warren, 2016.

580

581 Figure 5. Closure temperature cooling curves calculated using the method of Dygert and Liang 582 (2015) overlaid on measured closure temperatures for the REE and BKN thermometers.

583 Calculations were made assuming the cooling rate was constant throughout the cooling interval 584 recorded by these two thermometers. Initial temperatures $\left(T_{0}\right)$ for each cooling curve are 585 indicated right of the blue 1:1 line. Cooling rates calculated for a $0.5 \mathrm{~mm}$ radius opx grain $\left({ }^{\circ} \mathrm{C} / \mathrm{y}\right)$ 586 are indicated above the highest cooling curve; divide by 100 to rescale cooling rates for $5 \mathrm{~mm}$ 587 radius grains. For reference, the OM94 opx we analyzed have (on average) radii of 0.425 588 1.15mm (Table 1, Supplementary Figs. S7-S10); the abyssal peridotites apparently have larger 589 radii (up to 7.5-10mm according to Hellebrand et al., 2005 and Brunelli and Seyler, 2010). Black 590 lines originating from the $T_{0}=1400^{\circ} \mathrm{C}$ cooling curve indicate cooling rates for lower $T_{0}$. At slow 591 cooling rates, the curves converge to Eq. 1 (Dodson, 1973), the line left of and sub-parallel to the 592 1:1 line. Cooling curves were calculated with the closure temperature model of Ganguly and 593 Tirone (1999) using diffusion data for REE in opx for $T_{R E E}$ (Cherniak and Liang, 2007) and 594 diffusion data for Fe-Mg interdiffusion in cpx for $T_{B K N}$ (Dimanov and Wiedenbeck, 2006) (see 
595 explanation in the main text). Cpx in sample OM94-98, which plots left of the cooling curves,

596 may have exsolved from opx at low temperature (c.f. Supplementary Fig. S8). A meaningful

597 cooling rate for this sample cannot be determined.

599 Figure 6. Cooling rates of OM94 peridotites based on REE and BKN thermometry (red and blue 600 squares, Table 1 and Fig. 5) and Ca-in-Ol thermometry (green circles) based on olivine-cpx $601 \mathrm{Ca} / \mathrm{Mg}$ exchange. Also shown are rates for crustal gabbros (white circles; VanTongeren et al., 602 2008). Measured cooling rates are compared to cooling rates modeled using Eq. 2, and from 603 Cherkaoui et al. (2003). Conductive cooling models assume a thermal diffusivity of $1 \times 10^{-6}$ and 604 an initial temperature of $1350^{\circ} \mathrm{C}$. Blue squares are samples that may have cooling histories 605 affected by the obduction process. (a) Comparison with models that assume conductive cooling 606 of the lower crust and mantle. We assume hydrothermal circulation is pervasive in the upper 607 oceanic crust and fix the temperature $2.5 \mathrm{~km}$ beneath the seafloor at $200^{\circ} \mathrm{C}$. The results are almost 608 identical in simulations where temperature is fixed at $0^{\circ} \mathrm{C}$ at the same depth. These models 609 underestimate cooling rates of the lower crust and mantle. (b) Comparison with models that 610 assume the entire crust cools by hydrothermal circulation. In the model of Cherkaoui et al.

611 (2003), the crust has a permeability of $1 \times 10^{-14} \mathrm{~m}^{2}$. The conductive models assume cooling of the 612 mantle into a cold overlying crust with a constant temperature $\left(200^{\circ} \mathrm{C}\right)$. Again, the results are 613 almost identical in simulations where temperature at the crust-mantle interface is fixed at $0^{\circ} \mathrm{C}$ or $614350^{\circ} \mathrm{C}$.

615

616 References

617 Akizawa, N., Arai, S., 2009. Petrologic profile of peridotite layers under a possible Moho in 
the northern Oman ophiolite: an example from Wadi Fizh. J. Min. Pet. Sci., 104, 389394, doi:10.2465/jmps.090622a.

Akizawa, N., Arai, S., Tamura, A., 2012. Behavior of MORB magmas at uppermost mantle beneath a fast-spreading axis: an example from Wadi Fizh of the northern Oman

Barth, M.G., Mason, P.R.D., Davies, G.R., Dijkstra, A.H., Drury, M.R., 2003. Geochemistry of

Aldanmaz, E., 2012. Trace element geochemistry of primary mantle minerals in spinelperidotites from polygenetic MOR-SSZ suites of SW Turkey: constraints from an LAICP-MS study and implications for mantle metasomatism. Geol. J. 46, 59-76, doi:10.1002/gj.1336. the Othris Ophiolite, Greece: Evidence for refertilization? J. Petrol. 44, 1759-1785, doi:10.1093/petrology/egg058.

Batanova, V.G., Belousov, I.A., Savelieva, G.N., Sobolev, A.V., 2011. Consequences of channelized and diffuse melt transport in supra-subduction zone mantle: Evidence from the Voykar Ophiolite (Polar Urals). J. Petrol. 52, 2483-2521, doi:10.1093/petrology/egr053.

Boudier, F., Nicolas, A., Idelfonse, B., 1996. Magma chambers in the Oman ophiolite: fed from the top and the bottom. Earth Planet. Sci. Lett., 144, 239-250, 
doi:10.1016/0012-821X(96)00167-7.

642 Boyd, F.R., 1973. A pyroxene geotherm. Geochim. Cosmochim. Acta, 37(12), 2539-1546, doi:10.1016/0016-7037(73)90263-9.

644 Braun, M.G., 2004. Petrologic and microstructural constraints on focused melt transport in dunites and the rheology of the shallow mantle. PhD Thesis, MIT-WHOI Joint Program.

Brey, G.P., Köhler, T., 1990. Geothermobarometry in four-phase lherzolites II. New thermobarometers, and practical assessment of existing thermobarometers. J. Pet., 31(6),

Buck, W.R., 2000. Can downward flow of dense cumulate slurry through mush upper gabbros 1353-1378, doi:10.1093/petrology/31.6.1353.

Brunelli, D., Seyler, M., 2010. Asthenospheric percolation of alkaline melts beneath the St. Paul region (Central Atlantic Ocean). Earth Planet. Sci. Lett. 289, 393-405.

662 Cherniak, D.J., Dimanov, A., 2010. Diffusion in pyroxene, mica and amphibole. Rev. Mineral. Geochem., 72, 641-690, doi:10.2138/rmg.2010.72.14. 
664 Coogan, L.A., Jenkin, G.R.T., Wilson, R.N., 2002. Constraining the cooling rate of the 665 lower oceanic crust: a new approach applied to the Oman ophiolite. Earth Planet. Sci. Lett., 199, 127-146, doi:10.1016/S0012-821X(02)00554-X.

667 Coogan, L.A., Kasemann, S.A., Chakraborty, S., 2005a. Rates of hydrothermal cooling of 668 new oceanic upper curst derived from lithium-geospeedometry. Earth Planet. Sci. Lett., 240, 415-424, doi:10.1016/j.eps1.2005.09.020.

Coogan, L.A., Hain, A., Stahl, S., Chakraborty, S., 2005b. Experimental determination of the diffusion coefficient for calcium in olivine between $900^{\circ} \mathrm{C}$ and $1500^{\circ} \mathrm{C}$. Geochim. Cosmochim. Acta, 69(14), 3683-3694, doi:10.1016/j.gca.2005.03.002.

Coogan, L.A., Manning, C.E., Wilson, R.N., E.I.M.F., 2007a. Oxygen isotope evidence for short-lived high-temperature fluid flow in the lower oceanic crust at fast-spreading ridges. Earth Planet. Sci. Lett., 260, 524-536, doi:10.1016/j.eps1.2007.06.013.

Coogan, L.A., Jenkin, G.R.T., Wilson, R.N., 2007b. Contrasting cooling rates in the lower oceanic crust at fast- and slow-spreading ridges revealed by geospeedometry. J. Pet., 48(11), 2211-2231, doi:10.1093/petrology/egm057.

D’Errico, M.E., Warren, J.M., Godard, M., 2016. Evidence for chemically heterogeneous Arctic mantle beneath the Gakkel Ridge. Geochim. Cosmochim. Acta, 174, 291-312, doi:10.1016/j.gca.2015.11.017.

Dick, H.J.B., Bullen, T., 1984. Chromian spinel as a petrogenetic indicator in abyssal and alpine-type peridotites and spatially associated lavas. Conbrib. Mineral. Petrol., 86, 5476, doi:10.1007/BF00373711.

Dimanov, A., Wiedenbeck, M., 2006. (Fe,Mn)-Mg interdiffusion in natural diopside: effect of $\mathrm{pO}_{2}$. Eur. J. Mineral., 18, 705-718, doi:10.1127/0935-1221/2006/0018-0705. 
Dodson, M.H., 1973. Closure temperature in cooling geochronological and petrological systems. Conbrib. Mineral. Petrol., 40, 259-274, doi:10.1007/BF00373790.

Dygert, N., Liang, Y., 2015. Temperatures and cooling rates recorded in REE in coexisting pyroxenes in ophiolitic and abyssal peridotites. Earth Planet. Sci. Lett., 420, 151-161,

Dygert, N., Liang, Y., Kelemen, P.B., 2016. Formation of plagioclase lherzolite and associated dunite-harzburgite-lherzolite sequences by multiple episodes of melt percolation and melt-rock reaction: An example from the Trinity ophiolite, California, USA. J. Pet., 57, 815-838, doi:10.1093/petrology/egw018.

Eggins, S.M., Rudnik, R.L., McDonough, W.F., 1998. The composition of peridotites and their minerals: a laser-ablation ICP-MS study. Earth Planet. Sci. Lett., 154, 53-71, doi:10.1016/S0012-821X(97)00195-7.

Faak, K., Coogan, L.A., Chakraborty, S., 2015. Near conductive cooling rates in the upperplutonic section of crust formed at the East Pacific Rise. Earth Planet. Sci. Lett., 423, 3647, doi:10.1016/j.epsl.2015.04.025.

Faak, K., Gillis, K.M., 2016. Slow cooling of the lowermost oceanic crust at the fast-spreading East Pacific Rise. Geol. 44, 115-118, doi:10.1130/G37353.1.

Fabriès, J., 1979. Spinel-olivine geothermometry in peridotites from ultramafic complexes. Contrib. Mineral. Petrol. 69, 329-336.

Ganguly, J., Tirone, M., 1999. Diffusion closure temperature and age of a mineral with arbitrary extent of diffusion: theoretical formulation and applications. Earth Planet. Sci. Lett., 170, 131-140, doi:10.1016/S0012-821X(99)00089-8.

Garrido, C.J., Kelemen, P.B., Hirth, G., 2001. Variation of cooling rate with depth in lower 
crust formed at an oceanic spreading ridge: Plagioclase crystal size distributions in gabbros from the Oman ophiolite. Geochem. Geophys. Geosyst., 2(10), doi:10.1029/2000GC000136.

713 Godard, M., Jousselin, D., Bodinier, J.-L., 2000. Relationships between geochemistry and

Henstock, T.J., Woods, A.W., White, R.S., 1993. The accretion of oceanic crust by episodic sill intrusion. J. Geophys. Res., 98(B3), 4143-4161, doi:10.1029/92JB02661.

718

719

720

721

722

723

724

725

726 structure beneath a paleo-spreading centre; a study of the mantle section in the Oman Ophiolite. Earth Planet. Sci. Lett., 180, 133-148, doi:10.1016/S0012-821X(00)00149-7.

Hacker, B.R., Mosenfelder, J.L., Gnos, E., 1996. Rapid emplacement of the Oman ophiolite: Thermal and geochronologic constraints. Tectonics, 15(6), 1230-1247, doi:10.1029/96TC01973.

Hanghøj, K., Kelemen, P.B., Hassler, D., Godard, M., 2010. Composition and genesis of depleted mantle peridotites from the Wadi Tayin Massif, Oman ophiolite; major and trace element geochemistry, and Os isotopes and PGE systematics. J. Pet., 51(1-2), 201-227, doi:10.1093/petrology/egp007.

Hellebrand, E., Snow, J.E., Mostefaoui, S., Hoppe, P., 2005. Trace element distribution between orthopyroxene and clinopyroxene in peridotites from the Gakkel Ridge: A SIMS and NanoSIMS study. Contrib. Mineral. Petrol. 150, 486-504.

Jean, M.M., Shervais, J.W., Choi.S.-H., Mukasa, S.B., 2010. Melt extraction and melt refertilization in mantle peridotite of the Coast Range ophiolite: an LA-ICP-MS study. Contrib. Mineral. Petrol. 159, 113-136.

Kelemen, P.B., Shimizu, N., Salters, V.J.M., 1995. Extraction of mid-ocean-ridge basalt from the upwelling mantle by focused flow of melt in dunite channels. Nature, 375, 747- 
753, doi:10.1038/375747a0.

734 Kelemen, P.B., Hirth, G., Shimizu, N., Spiegelman, M., Dick, H.J.B., 1997. A review of melt migration processes in the adiabatically upwelling mantle beneath oceanic spreading

Kelemen, P.B., Koga, K., Shimizu, N., 1997. Geochemistry of gabbro sills in the crust-

Korenaga, J., Kelemen, P.B., 1998. Melt migration through the oceanic lower crust: a constraint from melt percolation modeling with finite solid diffusion. Earth Planet. Sci. Lett., 156, 1-11, doi:10.1016/S0012-821X(98)00004-1. 
Lasaga A. C. (1983) Geospeedometry: An extension of geothermometry. In Kinetics and Equilibrium in Mineral Reactions, edited by S. K. Saxena, p. 81-114. Advances in Physical Geochemistry 3. Springer, New York.

Lee, C.T.A., Harbert, A., Leeman, W.P., 2007. Extension of lattice strain theory to mineral/mineral rare-earth element partitioning: An approach for assessing disequilibrium and developing internally consistent partition coefficients between olivine, orthopyroxene, clinopyroxene and basaltic melt. Geochim. Cosmochim. Acta, 71, 481496, doi:10.1016/j.gca.2006.09.014.

Liang, Y., Sun, C., Yao, L., 2013. A REE-in-two-pyroxene thermometer for mafic and ultramafic rocks. Geochim. Cosmochim. Acta, 102, 246-260, doi:10.1016/j.gca.2012.10.035.

Liang, Y., 2014. Time scales of diffusive re-equilibration in bi-mineralic systems with and without a fluid or melt phase. Geochim. Cosmochim. Acta, 132, 274-287, doi:10.1016/j.gca.2014.02.008.

Liang, Y., 2015. A simple model for closure temperature of a trace element in cooling bimineralic systems. Geochim. Cosmochim. Acta, 165, 35-43.

Lindsley, D.H., 1983. Pyroxene thermometry. Am. Min., 68, 477-493.

Lindsley, D.H., Anderson, D.J., 1983. A two-pyroxene thermometer. J. Geophys. Res., 88, A887-A906.

Maclennan, J., Hulme, T., Sing, S.C., 2004. Thermal models of oceanic crustal accretion: Linking geophysical, geological and petrological observations. Geochem. Geophys. Geosyst., 5, doi:10.1029/2003GC000605.

MacLeod, C. J., Lissenberg, C.J., Bibby, L.E., 2013. "Moist MORB” axial magmatism in 
the Oman ophiolite: The evidence against a mid-ocean ridge origin. Geol., 41, 459-462, doi:10.1130/G33904.i.

781 Marchesi, C., Jolly, W.T., Lewis, J.F., Garrido, C.J., Proenza, J.A., Lidiak, E.G., 2011. Petrogenesis of fertile mantle peridotites from the Monte del Estado massif (Southwest Puerto Rico): a preserved section of Proto-Caribbean lithospheric mantle? Geol. Acta 9, 289-306, doi:10.1344/105.000001713.

Marchesi, C., Garrido, C.J., Proenza, J.A., Hidas, K., Varas-Reus, M.I., Butjosa, L., Lewis, J.F., 2016. Geochemical record of subduction initiation in the sub-arc mantle: Insights from the Loma Caribe peridotite (Dominican Republic). Lithos, 252-253, 1-15, doi:10.1016/j.lithos.2016.02.009.

Müntener, O., Manatschal, G., Desmurs, L., Pettke, T., 2010. Plagioclase peridotites in ocean-continent transitions: Refertilized mantle domains generated by melt stagnation in the shallow mantle lithosphere. J. Pet., 51(1-2), 255-294, doi:10.1093/petrology/egp087.

Nicolas, A., 1989. Structures of Ophiolites and Dynamics of Oceanic Lithosphere, Kluwer Academic Publishing, Dordrecht.

Nicolas, A., Boudier, F., Idelfonse, B., Ball, E., 2001. Accretion of Oman and United Arab Emirates ophiolite- Discussion of a new structural map. Marine Geophys. Res. 21, 147179.

Nicolas, A., Boudier, F., 2008. Large shear zones with no relative displacement. Terra Nova 20, 200-205.

Nickel, K.G., Green, D.H., 1985. Emperical geothermobarometry for garnet peridotites and implications for the nature of the lithosphere, kimberlites and diamonds. Earth Planet. Sci. Lett., 73, 158-170. 
802

803

804

805

806

807

808

809

810

811

812

813

814

815

816

817

818

819

820

821

822

823

824

Ozawa, K., 1984. Olivine-spinel geospeedometry: Analysis of diffusion-controlled $\mathrm{Mg}-\mathrm{Fe}^{2+}$ exchange. Geochim. Cosmochim. Acta, 48, 2597-2611, doi:10.1016/0016-7037(84)90308-9.

Pallister, J.S., Knight, R.J., 1981. Samail ophiolite plutonic suite: field relations, phase variation, cryptic variation and layering, and a model of a spreading ridge magma chamber. J. Geophys. Res., 86, 2673-2697, doi:10.1029/JB086iB04p02593.

Pearce, J.A., Alabaster, T., Shelton, A.W., Searle, M.P., 1981. The Oman Ophiolite as a Cretaceous arc-basin complex: Evidence and implications. Phil. Trans. Royal Soc., 300, 299-317, doi:10.1098/rsta.1981.0066.

Phipps Morgan, J., Chen, Y.J., 1993. The genesis of oceanic crust: Magma injection, hydrothermal circulation, and crustal flow. J. Geophys. Res., 98(B4), 6283-6297, doi:10.1029/92JB02650.

Putirka, K.D., 2008. Thermometers and barometers for volcanic systems. Rev. Mineral. Geochem., 69, 61-120, doi:10.2138/rmg.2008.69.3.

Quick, J.E., Denlinger, R.P., 1993. Ductile deformation and the origin of layered gabbro in ophiolites. J. Geophys. Res., 98(B8), 14015-14027, doi:10.1029/93JB00698.

Riches, A.J.V., Rogers, N.W., 2011. Mineralogical and geochemical constraints in the shallow origin, ancient veining, and multi-stage modification of the Lherz peridotite. Geochim. Cosmochim. Acta 75, 6160-6182.

Rioux, M., Bowring, S., Kelemen, P.B., Gordon, S., Dudas, F., Miller, R., 2012. Rapid crustal accretion and magma assimilation in the Oman-U.A.E. ophiolite: High precision U-Pb zircon geochronology of the gabbroic crust. J. Geophys. Res., 117(B7), doi:10.1029/2012JB009273. 
825 Rioux, M., Bowring, S., Kelemen, P.B., Gordon, S., Miller, R., Dudas, F., 2013. Tectonic

826 development of the Samail ophiolite: High-precision U-Pb zircon geochronology and

827 Sm-Nd isotopic constraints on crustal growth and emplacement. J. Geophys. Res.,

828 118(5), 2085-2101, doi:10.1002/jgrb.50139.

829 Rioux, M., Garber, J., Bauer, A., Bowring, S., Searle, M., Kelemen, P.B., Hacker, B., 2016.

830 Synchronous formation of the metamorphic sole and igneous crust of the Samail

$831 \quad$ ophiolite: New constraints on the tectonic evolution during ophiolite formation from

832 high-precision U-Pb zircon geochronology. Earth Planet. Sci. Lett. 451,

833 doi:10.1016/j.eps1.2016.06.051.

834 Seitz, H.M., Altherr, R., Ludwig, T.,1999. Partitioning of transition elements between

835 orthopyroxene and clinopyroxene in peridotitic and webseritic xenoliths: New empirical

836 geothermometers. Geochim. Cosmochim. Acta, 63(23-24), 3967-3982,

837 doi:10.1016/S0016-7037(99)00163-5.

838 Seyler, M., Brunelli, D., Toplis, M.J., Mével, C., 2011. Multiscale chemical heterogeneities

839 beneath the eastern Southwest Indian Ridge $\left(52^{\circ} \mathrm{E}-68^{\circ} \mathrm{E}\right)$ : Trace element compositions of

840 along-axis dredged peridotites. Geochem. Geophys. Geosyst. 12, Q0AC15,

$841 \quad$ doi:10.1029/2011GC003585.

842 Sinton, J.M., Detrick, R.S., 1992. Mid-ocean ridge magma chambers. J. Geophys. Res., 97,

843 197-216, doi:10.1029/91JB0258.

844 Sleep, N.H., 1975. Formation of oceanic crust: some thermal constraints. J. Geophys. Res., 80,

845 4037-4042, doi:10.1029/JB080i029p04037.

846 Smith, D., 2013. Olivine thermometry and source constraints for mantle fragments in the

847 Navajo Volcanic Field, Colorado Plateau, southwest United States: Implications for the 
mantle wedge. Geochem. Geophys. Geosyst., 14(3), 693-711, doi:10.1002/ggge.20065.

849 Sun, C., Liang, Y., 2014. An assessment of subsolidus re-equilibration on REE distribution among mantle minerals olivine, orthopyroxene, clinopyroxene, and garnet in peridotites. Chem. Geol., 372, 80-91.

852 Sun, C., Liang, Y., 2015. A REE-in-garnet-clinopyroxene thermobarometer for eclogites, granulites and garnet peridotites. Chem. Geol., 393-394, 79-92,

Takazawa, E., Okayasu, T., Satoh, K., 2003. Geochemistry and origin of the basal lherzolites from the northern Oman ophiolite (northern Fizh block). Geochem. Geophys. Geosyst., 4(2), 1021, doi:10.1029/2001GC000232.

Tilton, G.R., Hopson, C.A., Wright, J.E., 1981. Uranium-lead isotopic ages of the Samail doi:10.1016/j.chemgeo.2014.11.014.

VanTongeren, J.A., Kelemen, P.B., Hanghøj, K., 2008. Cooling rates in the lower crust of Ophiolite, Oman, with applications to Tethyan ocean ridge tectonics. J. Geophys. Res., 86, 2763-2775, doi:10.1029/JB086iB04p02763.

Turcotte, D.L., Schubert, G., 2002. Geodynamics, second ed. Cambridge University Press,

VanTongeren, J.A., Hirth, G., Kelemen, P.B., 2015. Constraints on the accretion of the the Oman ophiolite: Ca in olivine, revisited. Earth Planet. Sci. Lett., 267, 69-82, doi:10.1016/j.eps1.2007.11.034. gabbroic lower oceanic crust from plagioclase lattice preferred orientation in the Samail ophiolite. Earth Planet. Sci. Lett., 427, 249-261, doi:10.1016/j.eps1.2015.07.001.

Wang, C., Liang, Y., Xu, W., 2015. On the significance of temperature derived from major element and REE based two-pyroxene thermometers for mantle xenoliths from the North 
China Craton. Lithos, 224-225, 101-113, doi:10.1016/j.lithos.2015.01.022.

872 Warren, J.M., Shimizu, N., Sakagushi, C., Dick, H.J.B., Nakamura, E., 2009. An assessment of upper mantle heterogeneity based on abyssal peridotite isotopic compositions. J. Geophys. Res. 114, doi:10.1029/2008JB006186.

875 Warren, J.M., 2016. Global variations in abyssal peridotite compositions. Lithos, 248-251, 193219, doi:10.1016/j.lithos.2015.12.023.

877 Wells, P.R.A., 1977. Pyroxene thermometry in simple and complex systems. Contrib. Mineral. Petrol., 62, 129-139, doi:10.1007/BF00372872.

879 Witt-Eickschen, G., Seck, H.A., 1991. Solubility of Ca and Al in orthopyroxene from spinel peridotite: an improved version of an empirical geothermometer. Contrib. Mineral. Petrol., 106, 431-439, doi:10.1007/BF00321986.

882 Witt-Eickschen, G., O’Neill, H.S.C., 2005. The effect of temperature on the equilibrium distribution of trace elements between clinopyroxene, orthopyroxene, olivine, and spinel in upper mantle peridotite. Chem. Geol., 221, 65-101,

Wood, B.J., Banno, S., 1973. Garnet-orthopyroxene and orthopyrosene-clinopyroxene relationships in simple and complex systems. Contrib. Mineral.Petrol., 42, 109-124, doi:10.1007/BF00371501. and with application to REE-in-two-pyroxene thermometer. Geochim. Cosmochim. Acta, 162, 137-150, doi:10.1016/j.gca.2015.03.041. 
Table 1. Temperatures and cooling rates

\begin{tabular}{|c|c|c|c|c|c|c|c|c|c|c|c|c|c|c|c|}
\hline Sample & Depth (m) & $T_{R E E}$ & $1 \sigma$ & $\begin{array}{c}T_{C a-i n-} \\
\quad O P X\end{array}$ & $T_{B K N}$ & $\begin{array}{c}T_{C a-i n-} \\
\quad O l\end{array}$ & $\begin{array}{c}T_{O l-} \\
S_{p}\end{array}$ & $T_{W 77^{b}}$ & $T_{P 37^{\mathrm{c}}}^{\mathrm{c}}$ & $\begin{array}{c}T_{A l-i n-} \\
\quad d \\
O P X\end{array}$ & $\begin{array}{l}\text { Weighted } \\
\text { average } \\
\text { opx radius } \\
(\mathrm{mm})^{\mathrm{e}}\end{array}$ & $\begin{array}{c}\text { Weighted } \\
\text { average } \\
\text { cpx } \\
\text { radius } \\
(\mathrm{mm})^{\mathrm{e}} \\
\end{array}$ & $\begin{array}{c}\mathrm{dT} / \mathrm{dt} \\
\left({ }^{\circ} \mathrm{C} / \mathrm{y}\right) \\
\text { from } \\
T_{R E E} \text { and } \\
T_{B K N} \\
\end{array}$ & $\begin{array}{l}\text { Olivine } \\
\text { radius } \\
(\mathrm{mm})^{\mathrm{f}}\end{array}$ & $\begin{array}{c}\mathrm{dT} / \mathrm{dt} \\
\left({ }^{\circ} \mathrm{C} / \mathrm{y}\right) \text { from } \\
T_{\text {Ca-in-Ol }}\end{array}$ \\
\hline OM94-61 & 9565 & 1060 & 22 & 961 & 834 & 704 & 778 & 904 & 887 & 983 & 0.5 & 0.088 & $5.00 \mathrm{E}-03$ & 0.15 & $2.37 \mathrm{E}-03$ \\
\hline OM94-67 & 7860 & 1063 & 12 & 921 & 853 & 658 & 767 & 906 & 924 & 1062 & 0.8 & 0.29 & 2.73E-03 & 0.2 & $3.50 \mathrm{E}-04$ \\
\hline OM94-74 & 6430 & 1080 & 65 & 909 & 766 & 695 & 784 & 850 & 860 & 952 & 0.43 & 0.125 & $6.92 \mathrm{E}-04$ & 0.15 & $1.85 \mathrm{E}-03$ \\
\hline OM94-79 & 4895 & 1104 & 36 & 892 & 769 & 633 & 767 & 851 & 835 & 1003 & 0.44 & 0.11 & $7.75 \mathrm{E}-04$ & 0.1 & $6.27 \mathrm{E}-04$ \\
\hline OM94-98 & 2880 & 1238 & 41 & 906 & 719 & 780 & 783 & 825 & 830 & 1010 & 0.6 & 0.058 & $-g$ & 0.5 & $-g$ \\
\hline OM94-101 & 2150 & 1232 & 6 & 982 & 816 & 706 & 780 & 881 & 861 & 948 & 0.43 & 0.070 & $6.92 \mathrm{E}-03$ & 0.15 & $2.50 \mathrm{E}-03$ \\
\hline OM94-106 & 970 & 1325 & 5 & 1074 & 973 & 791 & 811 & 990 & 1005 & 1016 & 0.5 & 0.50 & $2.50 \mathrm{E}-01$ & 0.425 & $2.83 \mathrm{E}-03$ \\
\hline OM94-114 & 520 & 1333 & 18 & 1127 & 1058 & 855 & 766 & 1055 & 1072 & 1026 & 1.15 & 0.16 & $2.84 \mathrm{E}-01$ & 0.2 & $5.46 \mathrm{E}-02$ \\
\hline
\end{tabular}

${ }^{\mathrm{a} C}$ Calculated with the thermometer of Fabriès, 1979 using olivine and spinel data from Hanghøj et al., 2010.

${ }^{\mathrm{b}}$ Wells, 1977

${ }^{\mathrm{c}}$ Equation 37, Putirka, 2008

${ }^{\mathrm{d}}$ Witt-Eickschen and Seck, 1991. Note the pyroxene compositions are outside the calibration range for this thermometer.

${ }^{\mathrm{e}}$ Grain size is estimated assuming the shortest bisector establishes the effective grain size. Grain size is weighted by the number of laser spots in a grain of a particular size.

${ }^{\mathrm{f}}$ Single olivine grains or two grains of approximately the same size were analyzed.

${ }^{\mathrm{g}}$ Cooling rate cannot be obtained for this sample, see main text. 
Figure Summary (Low-Resolution)

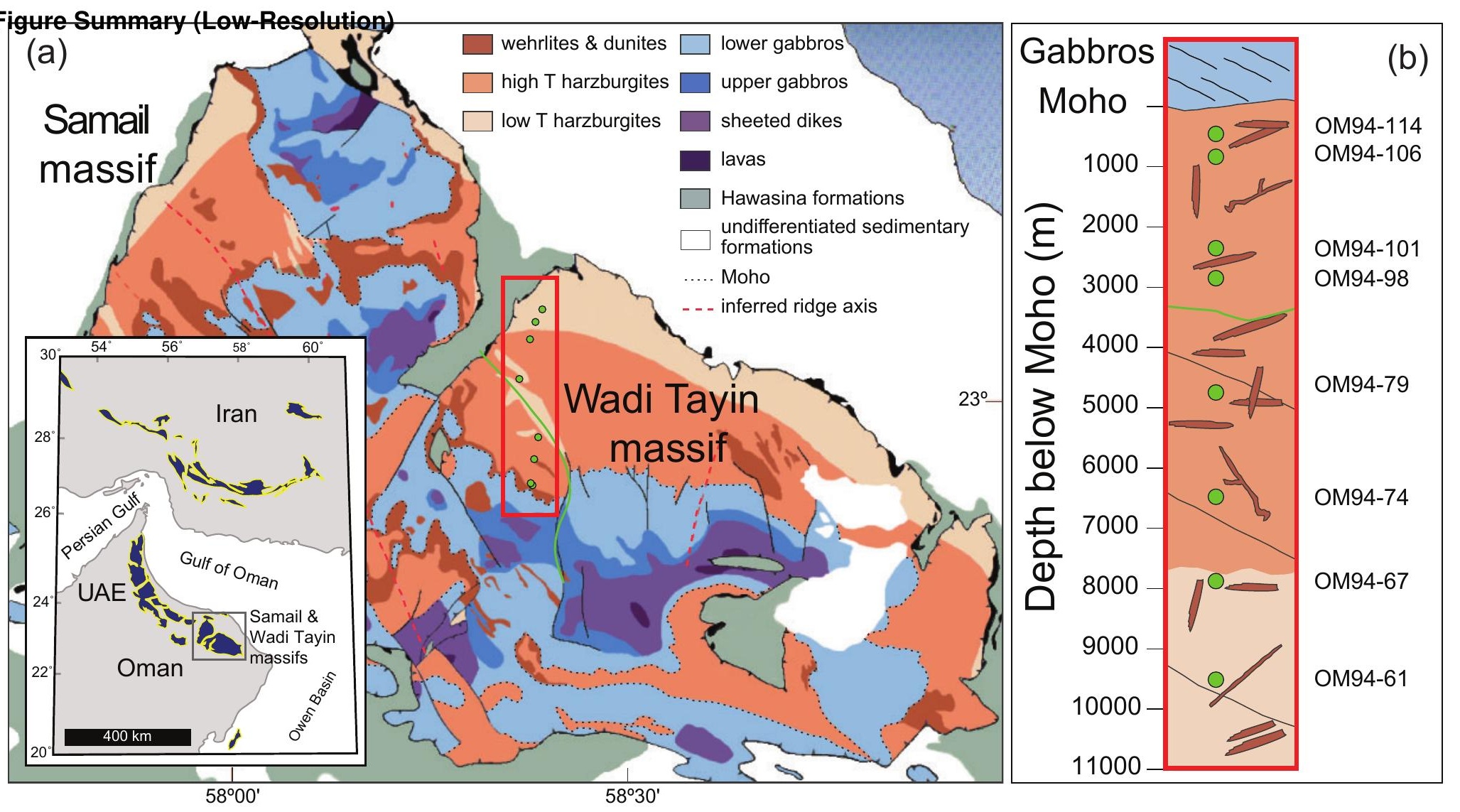




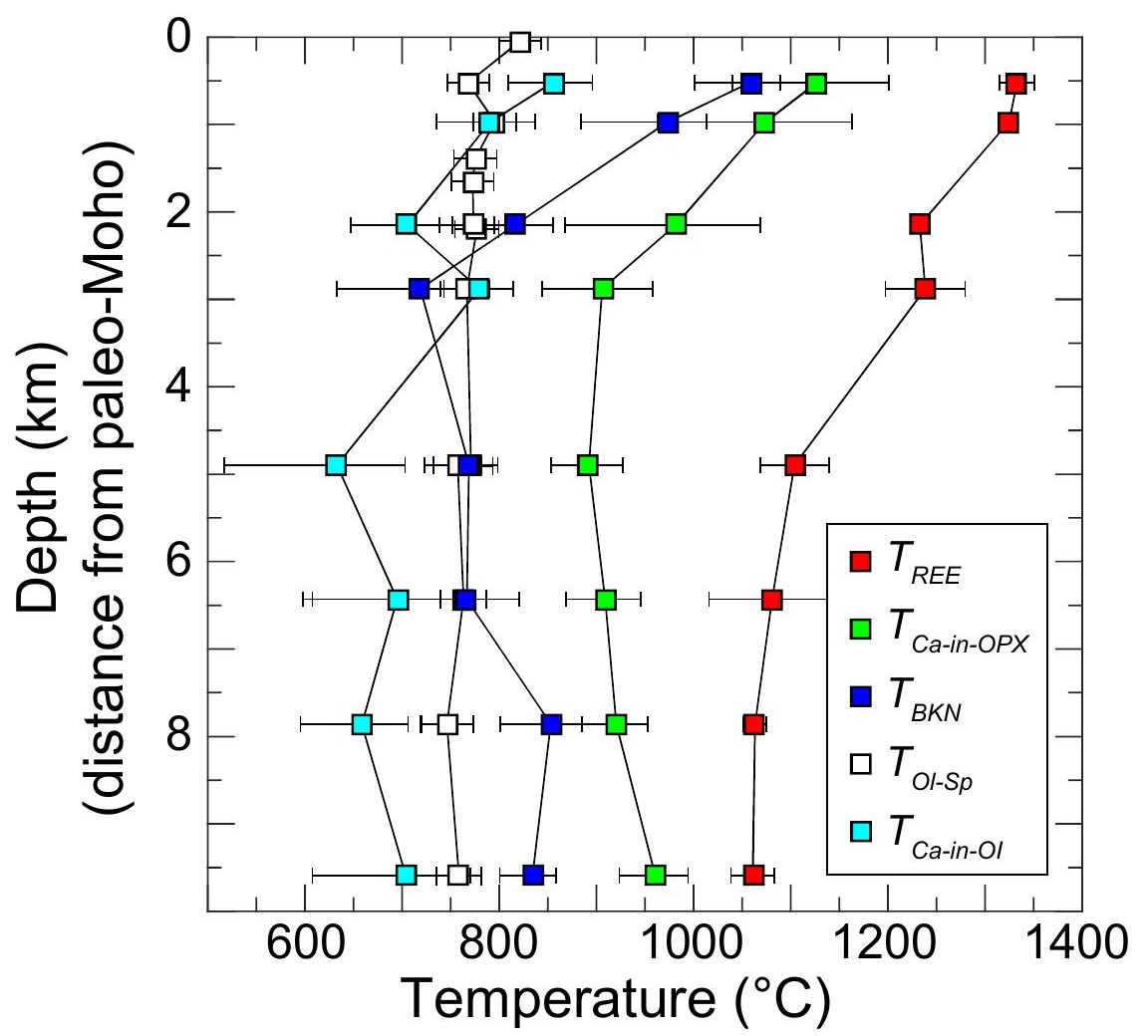



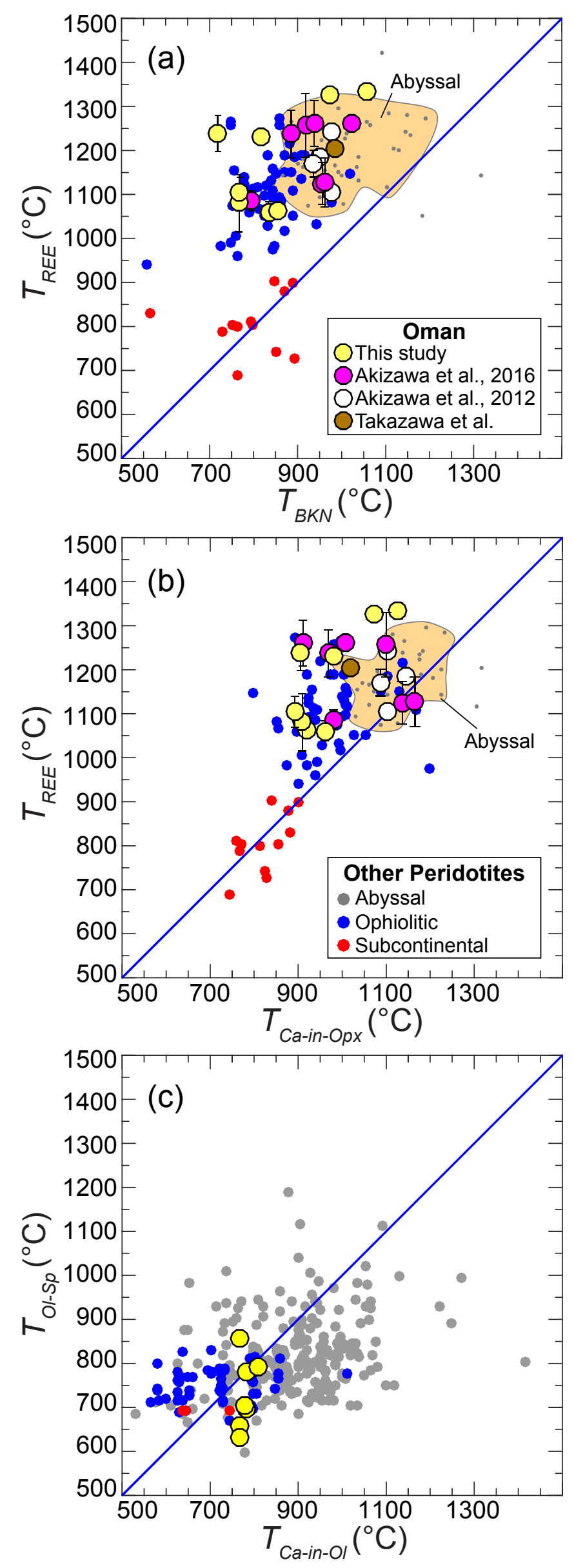


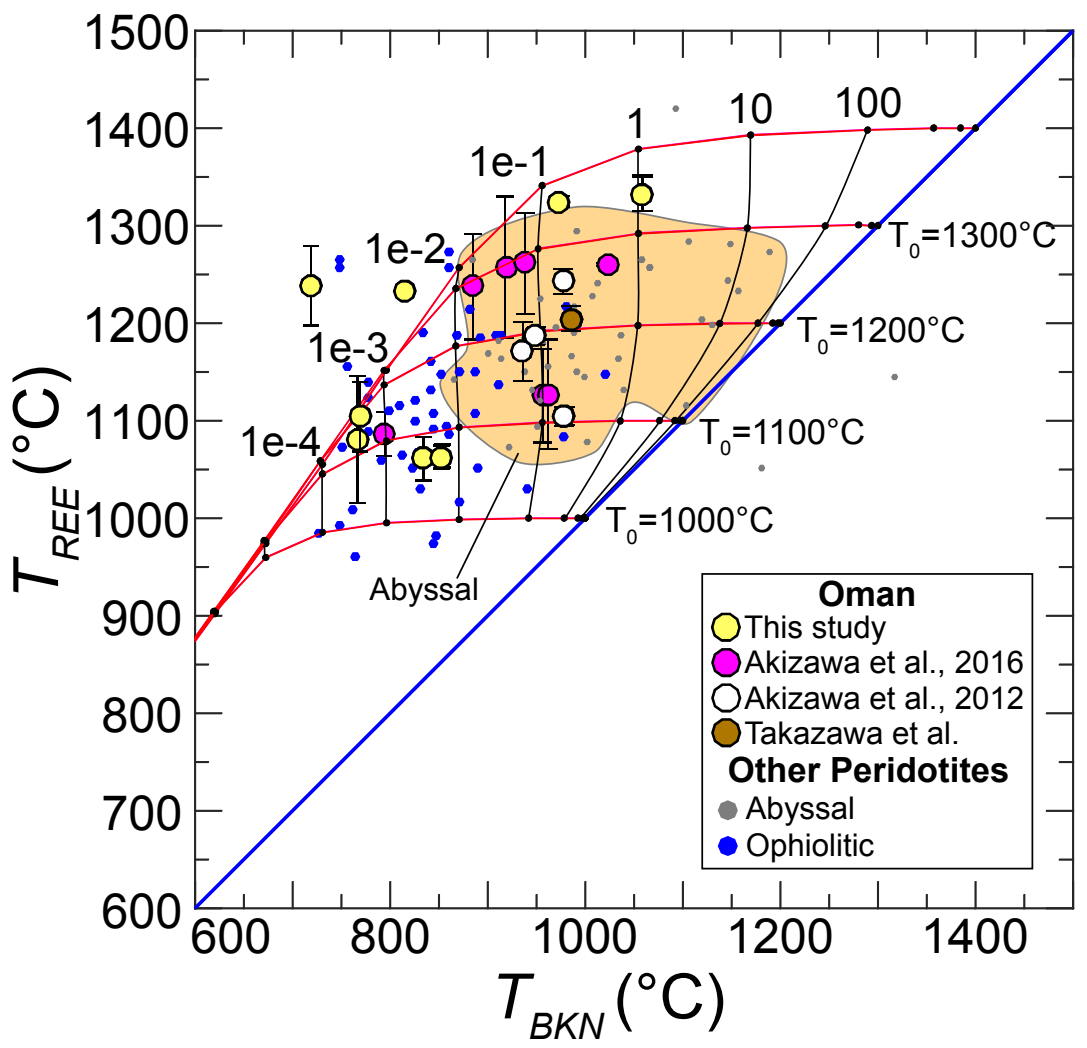




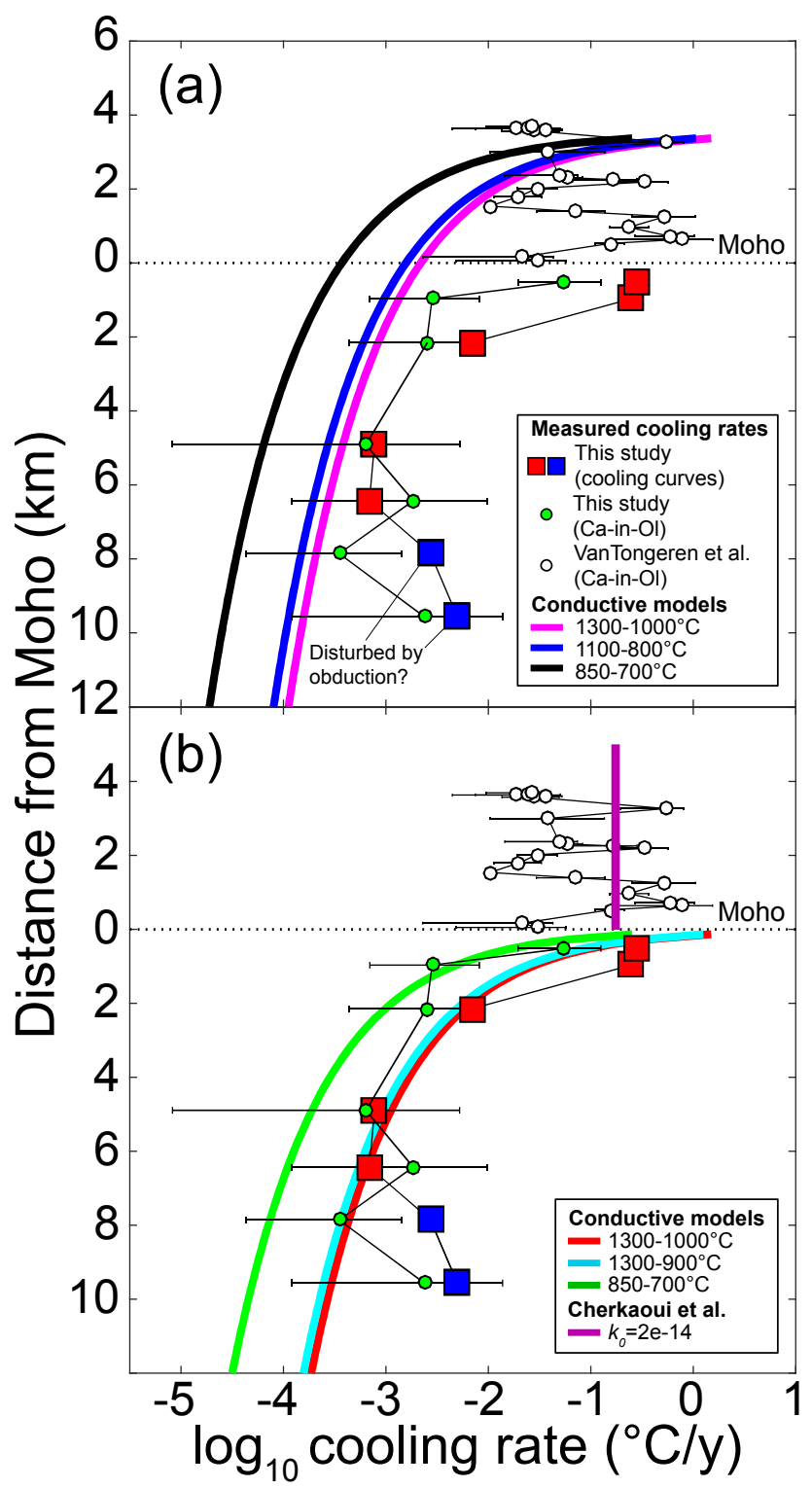

